\title{
Leber's hereditary optic neuropathy: correlations between mitochondrial genotype and visual
} outcome

\author{
R J Oostra, P A Bolhuis, F A Wijburg, G Zorn-Ende, E M Bleeker-Wagemakers
}

\begin{abstract}
Leber's hereditary optic neuropathy (LHON) is a maternally inherited disease associated with mitochondrial DNA (mtDNA) mutations. We describe the distribution of seven different mtDNA mutations and the clinical findings in 334 LHON patients belonging to 29 families. Mutations described only in LHON at nucleotide positions 11778, 3460, and 14484 were found in 15 , two, and nine families respectively. In three families none of these mutations was found. $\mathrm{Mu}$ tations described in LHON but also in controls at nucleotide positions 15257, 13708,4917 , and 4216 were found in one, 10, three and 12 families respectively. Combinations of mtDNA mutations were found in most families. The patient population mainly consisted of $79 \cdot 2 \%$ to 89.5\% males except for one family with only 10 of 17 patients being males (58.9\%, $p \approx 0.036)$. In 11 families only the 11778 mutation was found; in this group (WX) the affected males had a mean age of onset of 29.2 years and a mean visual outcome of $0 \cdot 113$. In seven families the 14484, 13708, and 4216 mutations were found; in this group (MA) the affected males had a mean age of onset of 22.0 years and a mean visual outcome of 0.442 . In two families no mutation was found at all; in this group (YX) the affected males had a mean age of onset of 18.9 years and a mean visual outcome of $0 \cdot 167$. The mean age of onset in the WX group is significantly higher than in the MA group $(p \leqslant 0.001)$ and in the YX group $(p \approx 0.01)$. The mean visual outcome in the $M A$ group is significantly better than in the WX group ( $\leqslant \leqslant 0.001)$ and in the YX group $(p \approx 0 \cdot 05)$. No significant clinical differences were found between families exhibiting only the 11778 mutation and those with additional mutations at np 13708,4917 , or 4216 , suggesting that these mutations are of little phenotypic importance. Other mutations were present in relatively small numbers of patients. These results show that the clinical severity is dependent on the mitochondrial genotype.
\end{abstract}

\section{(f Med Genet 1004;31:280-286)}

Leber's hereditary optic neuropathy (LHON) is a maternally inherited disease characterised by (sub)acute loss of central vision owing to severe bilateral optic atrophy. The clinical picture of LHON exhibits marked interpersonal variation, especially with regard to age of onset, progression rate, final visual loss, and accompanying disorders. ${ }^{1}$

In most patients the age of onset is between 17 and 23 years, but it may range from less than 5 to more than 65 years. ${ }^{1}$ The onset of visual loss is usually quite sudden. During a period of three to six months (the acute stage) vision rapidly deteriorates to finger counting or perception of hand movements. Visual loss may, however, be insidious and can remain subclinical for a long time. In the chronic stage a slight recovery often occurs and in about two years after the onset visual acuity stabilises between 0.05 and $0 \cdot 10$. The final outcome may, however, vary from little more than light perception to nearly complete visual recovery. The interval between the onset in each eye usually amounts to a few weeks or months but it may be absent (that is, both eyes being simultaneously affected) or cover more than two years. ${ }^{1}$ In some pedigrees accompanying abnormalities, especially neurological disorders, have a high incidence not only in LHON patients but also in their matrilineal sibs. ${ }^{1-8}$

The strictly maternal inheritance could be explained by involvement of mitochondrial DNA (mtDNA). Indeed Wallace et $a l^{9}$ discovered that in several LHON families a mitochondrial DNA (mtDNA) mutation was present in one of the genes coding for a protein subunit of Complex 1 of the respiratory chain (ND4) at nucleotide position 11778. Subsequent studies showed that this mutation occurred in about a half of the pedigrees examined, in patients as well as in healthy family members, but not in non-LHON related controls. ${ }^{10-12}$

Up till now 10 other mtDNA mutations associated with LHON have been described, though some of them do not alter evolutionarily conserved amino acids and are not as specific for LHON as the 11778 mutation; most of the mutations occur in patterns of two or 
Table 1 Primers and restriction enzymes used in the detection of mtDNA mutations

\begin{tabular}{|c|c|c|c|c|}
\hline \multirow[b]{2}{*}{$\begin{array}{l}\text { Mutation } \\
n t\end{array}$} & \multirow[b]{2}{*}{ Gene } & \multicolumn{2}{|l|}{ Primers } & \multirow[b]{2}{*}{$\begin{array}{l}\text { Restriction } \\
\text { enzyme }\end{array}$} \\
\hline & & $\begin{array}{l}\text { Forward } \\
n p\end{array}$ & $\begin{array}{l}\text { Reverse } \\
n p\end{array}$ & \\
\hline $\begin{array}{r}3460 \\
4216 \\
4917 \\
11778 \\
13708 \\
14484 \\
15257\end{array}$ & $\begin{array}{l}\text { ND1 } \\
\text { ND1 } \\
\text { ND2 } \\
\text { ND4 } \\
\text { ND5 } \\
\text { ND6 } \\
\text { cytB }\end{array}$ & $\begin{array}{r}3116-3135 \\
4006-4077 \\
4704-4721 \\
11501-11520 \\
13570-13587 \\
14389-14410 \\
15101-15117\end{array}$ & $\begin{array}{r}3570-3549 \\
4670-4653 \\
5120-5103 \\
11900-11881 \\
14007-13990 \\
14538-14518 \\
15438-15422\end{array}$ & $\begin{array}{l}\text { BsaHI } \\
\text { NlaIII } \\
\text { MaeI } \\
\text { MaeIII } \\
\text { Bst NI } \\
\bar{A} c c \mathrm{I}\end{array}$ \\
\hline
\end{tabular}

more. ${ }^{811-14}$ Since all matrilineal family members carry the mtDNA mutation(s) involved, but only $50 \%$ of the males and $15 \%$ of the females develop LHON, as indicated by large scale studies, ${ }^{115}$ it has been suggested that an $\mathrm{X}$ linked susceptibility gene contributes to the liability to develop LHON. ${ }^{1617}$

Because of the lack of pathognomonic symptoms and the diversity of clinical findings, a firm diagnosis required either a previous history of the disease in matrilineal family members or the establishment of one or more of the mtDNA mutations described.

Here we describe 334 LHON patients in 29 different pedigrees tested for seven different mtDNA mutations in order to see whether there is any correlation between mutation pattern and visual outcome. This correlation has been suggested before ${ }^{81819}$ but, to our knowledge, has never been established in a large scale study.

\section{Material and methods}

We investigated mtDNA of 56 LHON patients in 36 pedigrees and of 30 of their unaffected sibs. These persons were tested for mutations in the Complex 1 genes ND1 at nucleotide position (np) 3460 and 4216, ND2 at np 4917, ND4 at np 11778, ND5 at np 13708, and ND6 at 14484 . They were also tested for a mutation in the cytochrome b oxidase (cyt b) gene (Complex 3) at np 15257. These mutations were described earlier in relation to LHON by Wallace et al ${ }^{p}$ (11778), by Johns and Berman ${ }^{11}(4216,4917$, and 13708), by Huoponen et $a l^{13}$ and Howell et $a l^{14}$ (3460), by Johns and Neufeld ${ }^{20}$ (15257), and by Howell $e t a l^{\top}$ and Johns $e t a l^{11}$ (14484). MtDNA was amplified in polymerase chain reactions (PCR) of DNA samples obtained from white blood cells. PCR primers are indicated in table 1. Amplified DNA was restricted with enzymes shown in table 1 and the fragments were analysed by polyacrylamide gel electrophoresis and ethidium bromide staining. The 14484 mutation was detected by means of direct sequencing. The reverse primer (table 1) was biotinylated and the PCR product was isolated by means of magnetic streptavidine beads. The sequence reaction was carried out with fluorescein labelled primer (14389-14421) and recorded on a Millipore Basestation.

Many of these patients belonged to one of the pedigrees investigated by Van Senus. ${ }^{1}$ Assuming that all family members of a matrilineal pedigree have the same mitochondrial mutations, we included in this study many of the affected sibs of investigated patients who were described by Van Senus, thereby expanding the total number of LHON patients from 56 to 341 . Of the patients who are linked to one of the matrilineal pedigrees, all those who experienced visual loss at some time during their lives and and who exhibited ophthalmological abnormalities suggestive of either the acute or the chronic stage of the disease were included. Isolated patients, who have no known affected matrilineal sibs, were included only when any other cause of optic nerve atrophy, such as intoxication or multiple sclerosis, appeared improbable. Isolated patients without a history of normal vision were excluded since they could be suffering from congenital blindness, because of, for example, autosomal dominant optic nerve atrophy.

Since we obtained the clinical data by retrospective analysis of up to 60 year old medical records we often came upon considerable gaps in the information relevant to our study, especially where it concerned anamnestic details, perimetric findings, and colour vision. Moreover, many patients were not examined at our institution so we were entirely reliant on the reports of others. We therefore concentrate this study on the following paramaters: (1) sex, (2) age of onset, and (3) final visual outcome.

\section{Results}

GENOTYPES

We found that the seven mtDNA mutations occurred in different patterns in the pedigrees tested. The 11778,3460 , and the 14484 mutations are thought to be the most important mutations pathogenetically since they alter evolutionarily highly conserved amino acids and have never been reported in non-LHON related persons, unlike the other mutations. We, therefore, differentiated the pedigrees in which only one of the LHON specific mutations occurred (coded W·, $\mathrm{H} \cdot$, and $M \cdot$ respect-

Table 2 Grouping of the initial 36 pedigrees according to their mutation pattern and number of pedigrees in each group

\begin{tabular}{llll}
\hline & Less specific mutations & \\
\cline { 2 - 4 } $\begin{array}{lll}100 \% \text { specific } \\
\text { mutations }\end{array}$ & $13708(\cdot A)$ & $4917(\cdot B)$ & Neither 13708 \\
nor $4917(\cdot X)$
\end{tabular}

All pedigrees in the WB, MA, and YA groups exhibit the mutation at np 4216; all pedigrees in the other groups do not. One pedigree in the MA group, coded MA*, exhibits the 15257 mutation. 
ively) from those without these mutations (coded Y·). The 11778,3460 , and 14484 mutations did not appear simultaneously in the pedigrees tested. In these four groups, W., H., $\mathrm{M}$, and $\mathrm{Y} \cdot$, either the $13708(\operatorname{coded} \cdot \mathrm{A})$ or the 4917 mutation (coded $\cdot B$ ) or neither (coded $\cdot X$ ) were found. The eight resulting mutation patterns we found in the pedigrees investigated are listed in table 2.

The 4216 mutation occurred only in association with the 13708 or the 4917 mutation. For reasons dealt with later (see Discussion) we did not differentiate the patterns for the presence of the $\mathbf{4 2 1 6}$ mutation. The 15257 mutation was found in only one small family, comprising a male and his maternally related uncle. Besides this mutation, the 14484,13708 , and 4216 mutations were also present $\left(\mathrm{MA}^{*}\right)$ in this family.

We found seven patients without known affected matrilineal sibs in whom only the nonspecific mutation at np 4917 was present (YB) or none of the seven mutations at all (YX). They were excluded from this study as the diagnosis of LHON in these patients could not be made with certainty. The remaining cohort therefore consisted of 334 patients in 29 pedigrees. The mutation patterns in these families are: WA (11778 and 13708), WB (11778, 4917, and 4216), WX (only 11778), HX (only 3460), MA (14484, 13708, and 4216), MA* (14484, 13708, 4216, and 15257), MX (only 14484), YA (13708 and 4216), and YX (none).

Heteroplasmy (the presence of more than

Table 3 Genotypic and phenotypic characteristics of the pedigrees

\begin{tabular}{|c|c|c|c|c|c|c|c|c|c|c|c|c|}
\hline \multirow[b]{3}{*}{ Pedigree } & \multirow[b]{3}{*}{ Genotype } & \multirow[b]{3}{*}{ Sex } & \multicolumn{5}{|c|}{ No of visually affected persons } & \multirow{2}{*}{\multicolumn{2}{|c|}{$F V A$}} & \multirow{2}{*}{\multicolumn{3}{|c|}{ Age of onset (y) }} \\
\hline & & & \multirow{2}{*}{$\begin{array}{l}\text { Total } \\
\text { known }\end{array}$} & \multirow{2}{*}{$\begin{array}{l}\text { Total } \\
\text { described }\end{array}$} & \multirow{2}{*}{$\begin{array}{l}\text { With } \\
\text { known } \\
F V A\end{array}$} & \multirow{2}{*}{$\begin{array}{l}\text { With } \\
F V A> \\
0 \cdot 1\end{array}$} & \multirow{2}{*}{$\begin{array}{l}\text { With } \\
F V A \geqslant \\
0.5\end{array}$} & & & & & \\
\hline & & & & & & & & Mean & Median & Mean & Median & Range \\
\hline $\mathbf{S O 0 4}$ & WA & $\underset{\mathbf{F}}{\mathbf{M}}$ & $\underset{3}{16(84 \cdot 2 \%)}$ & $\begin{array}{r}13 \\
3\end{array}$ & $\begin{array}{r}12 \\
2\end{array}$ & $2(16 \cdot 7 \%)$ & $1(8 \cdot 3 \%)$ & $\begin{array}{l}0.079 \\
0.046\end{array}$ & $\begin{array}{l}0.017 \\
0.046\end{array}$ & $\begin{array}{l}26 \cdot 3 \\
18 \cdot 3\end{array}$ & $\begin{array}{l}23 \\
19\end{array}$ & $\begin{array}{l}11-52 \\
16-20\end{array}$ \\
\hline SO20 & WB & $\begin{array}{l}\mathrm{M} \\
\mathbf{F}\end{array}$ & $\begin{array}{r}3 \\
2\end{array}$ & $\begin{array}{l}3 \\
6 \\
2\end{array}$ & 4 & 1 & 1 & 0.183 & 0.014 & $\begin{array}{l}26.5 \\
63.5\end{array}$ & $\begin{array}{l}28 \\
63.5\end{array}$ & $\begin{array}{l}17-35 \\
58-69\end{array}$ \\
\hline S050 & WB & $\begin{array}{l}\mathbf{F} \\
\mathbf{F}\end{array}$ & $\begin{array}{l}2 \\
4 \\
0\end{array}$ & $\begin{array}{r}2 \\
-\quad 3\end{array}$ & $\begin{array}{r}0 \\
- \\
-\end{array}$ & -0 & $=$ & 0.059 & 0.056 & $\begin{array}{l}25 \cdot 7 \\
-\end{array}$ & 23 & $\begin{array}{r}30-46 \\
-\quad 46\end{array}$ \\
\hline S055 & WB & $\underset{F}{\mathrm{M}}$ & $\begin{array}{l}0 \\
3 \\
0\end{array}$ & 3 & 1 & $\overline{0}$ & $\overline{-}$ & $\overline{-}$ & 0.033 & 28 & 24 & $20-40$ \\
\hline Total & WB & $\mathbf{M}$ & $17(89 \cdot 5 \%)$ & - & 8 & $1(12 \cdot 5 \%)$ & $\overline{1}(12 \cdot 5 \%)$ & $\overline{0} \cdot 118$ & $\overline{0} .044$ & $\overline{26.7}$ & $\overline{23 \cdot 5}$ & $8-46$ \\
\hline S014 & $\mathbf{w x}$ & $\begin{array}{l}\mathbf{F} \\
\mathbf{M} \\
\mathbf{F}\end{array}$ & $\begin{array}{r}2 \\
11 \\
4\end{array}$ & $\begin{array}{l}2 \\
9 \\
2\end{array}$ & $\begin{array}{l}\mathbf{0} \\
7 \\
2\end{array}$ & $\begin{array}{l}- \\
0 \\
0\end{array}$ & $\begin{array}{l}\overline{-} \\
\overline{-}\end{array}$ & $\begin{array}{l}\overline{0.034} \\
0.009\end{array}$ & $\begin{array}{l}\overline{0.017} \\
0.009\end{array}$ & $\begin{array}{l}63 \cdot 5 \\
33 \cdot 1 \\
35 \cdot 5\end{array}$ & $\begin{array}{l}63 \cdot 5 \\
32 \\
35 \cdot 5\end{array}$ & $\begin{array}{l}58-69 \\
18-54 \\
19-52\end{array}$ \\
\hline S018 & $w x$ & M & $\begin{array}{r}4 \\
36 \\
3\end{array}$ & $\begin{array}{r}30 \\
3\end{array}$ & 22 & $\begin{array}{r}7 \\
-\end{array}$ & 4 & 0.193 & 0.003 & $\begin{array}{l}28.9 \\
24.7\end{array}$ & $\begin{array}{l}28 \\
13\end{array}$ & $\begin{array}{r}6-57 \\
60-51\end{array}$ \\
\hline S022 & $w x$ & $\begin{array}{l}\mathrm{M} \\
\mathrm{F}\end{array}$ & $\begin{array}{r}12 \\
2\end{array}$ & $\begin{array}{r}11 \\
2\end{array}$ & $\begin{array}{l}6 \\
2\end{array}$ & $\begin{array}{l}1 \\
2\end{array}$ & $\begin{array}{l}0 \\
1\end{array}$ & $\begin{array}{l}0.044 \\
0.475\end{array}$ & $\begin{array}{l}0.017 \\
0.475\end{array}$ & $\begin{array}{l}26.5 \\
21.5\end{array}$ & $\begin{array}{l}25.5 \\
21.5\end{array}$ & $\begin{array}{r}7-42 \\
8-35\end{array}$ \\
\hline S025 & $w X$ & $\begin{array}{l}\mathrm{M} \\
\mathrm{F}\end{array}$ & $\begin{array}{r}17 \\
1\end{array}$ & $\begin{array}{r}14 \\
0\end{array}$ & $\begin{array}{r}8 \\
-\end{array}$ & $\begin{array}{r}0 \\
-\end{array}$ & $=$ & 0.031 & 0.029 & $35 \cdot 4$ & 32 & $14-61$ \\
\hline$S 042$ & $w x$ & $\begin{array}{l}\mathrm{M} \\
\mathrm{F}\end{array}$ & $\begin{array}{l}1 \\
9 \\
1\end{array}$ & $\begin{array}{l}7 \\
1\end{array}$ & $\begin{array}{l}3 \\
0\end{array}$ & $\begin{array}{r}0 \\
-\end{array}$ & - & 0.046 & 0.02 & $23 \cdot 3$ & $\begin{array}{l}27 \\
39\end{array}$ & $\begin{array}{l}8-40 \\
-\end{array}$ \\
\hline S065 & WX & $\underset{F}{M}$ & $\begin{array}{l}1 \\
0\end{array}$ & -1 & 1 & 0 & $\overline{-}$ & $\overline{-}$ & 0.033 & - & 21 & - \\
\hline S066 & $w \mathbf{X}$ & $\begin{array}{l}\mathbf{M} \\
\mathbf{F}\end{array}$ & $\begin{array}{l}0 \\
1 \\
1\end{array}$ & $\begin{array}{l}1 \\
0\end{array}$ & 1 & 0 & - & - & 0.003 & - & 25 & - \\
\hline S067 & $\mathbf{w x}$ & $\begin{array}{l}\mathbf{M} \\
\mathbf{F}\end{array}$ & $\begin{array}{l}1 \\
2 \\
0\end{array}$ & $\begin{array}{r}2 \\
-\quad\end{array}$ & 2 & 1 & -0 & 0.15 & 0.15 & $20 \cdot 5$ & $20 \cdot 5$ & $18-23$ \\
\hline S072 & $w \mathbf{x}$ & $\begin{array}{l}\mathbf{M} \\
\mathbf{F}\end{array}$ & $\begin{array}{l}0 \\
3 \\
0\end{array}$ & -3 & 1 & 0 & $\begin{array}{l}\bar{z} \\
\overline{-}\end{array}$ & - & 0.042 & 22 & 24 & $-9-33$ \\
\hline S080 & $W X$ & $\begin{array}{l}\mathbf{M} \\
\mathbf{F}\end{array}$ & $\begin{array}{l}0 \\
3 \\
0\end{array}$ & -2 & 2 & 1 & 0 & $\overline{0.225}$ & 0.225 & 23 & 23 & $10-36$ \\
\hline S086 & $w x$ & $\begin{array}{l}M \\
F\end{array}$ & $\begin{array}{l}1 \\
0\end{array}$ & -1 & -0 & $\overline{-}$ & $\overline{-} \quad$ & - & $=$ & - & 46 & $=$ \\
\hline Total & $\mathbf{w x}$ & $\begin{array}{l}\mathbf{M} \\
\mathbf{F}\end{array}$ & $\begin{array}{l}96(88 \cdot 8 \%) \\
12\end{array}$ & $\begin{array}{r}80 \\
8\end{array}$ & $\begin{array}{r}53 \\
4\end{array}$ & $\begin{array}{r}10(18.9 \%) \\
2(50.0 \%)\end{array}$ & $\begin{array}{l}4(7 \cdot 6 \%) \\
1(25 \cdot 0 \%)\end{array}$ & $\begin{array}{l}0.113 \\
0.242\end{array}$ & $\begin{array}{l}\overline{0.033} \\
0.083\end{array}$ & $\begin{array}{l}-79 \cdot 2 \\
28 \cdot 4\end{array}$ & $\begin{array}{l}27 \\
27\end{array}$ & $\begin{array}{l}6-61 \\
8-52\end{array}$ \\
\hline S069 & $H X$ & $\underset{F}{M}$ & $\begin{array}{l}1 \\
0\end{array}$ & -1 & 1 & ${ }_{-}$ & $=$ & - & 0.003 & - & 20 & - \\
\hline S083 & $\mathrm{HX}$ & $\mathrm{M}$ & $\begin{array}{l}1 \\
0\end{array}$ & -1 & 1 & 1 & 1 & $\bar{z}$ & 0.8 & $\bar{z}$ & 18 & - \\
\hline Total & $\mathbf{H X}$ & $\mathbf{F}$ & $\mathbf{2}$ & -2 & -2 & 1 & 1 & $0 \cdot 4$ & $\overline{0} \cdot 4$ & 19 & 19 & ${ }_{-}^{18-20}$ \\
\hline S001 & MA & $\begin{array}{l}\mathbf{M} \\
\mathbf{F}\end{array}$ & $\begin{array}{r}107 \\
10\end{array}$ & $\begin{array}{l}80 \\
10\end{array}$ & $\begin{array}{r}-77 \\
9\end{array}$ & $\begin{array}{r}31 \\
5\end{array}$ & $\begin{array}{r}- \\
25 \\
4\end{array}$ & $\begin{array}{l}\overline{0} \cdot 391 \\
0 \cdot 388\end{array}$ & $\begin{array}{l}-\overline{2} \\
0 \cdot 167\end{array}$ & $\begin{array}{l}-24 \cdot 6 \\
26.9\end{array}$ & $\begin{array}{l}\overline{22} \\
24 \cdot 5\end{array}$ & $\begin{array}{r}9-58 \\
10-60\end{array}$ \\
\hline S005 & MA & $\mathrm{M}$ & $\begin{array}{r}20 \\
8\end{array}$ & $\begin{array}{r}18 \\
8\end{array}$ & 12 & $\begin{array}{r}10 \\
4\end{array}$ & $\begin{array}{l}6 \\
2\end{array}$ & $\begin{array}{l}0.524 \\
0.255\end{array}$ & 0.575 & $\begin{array}{l}20.9 \\
16 \cdot 2\end{array}$ & 15 & \\
\hline S008 & MA & $\mathrm{M}$ & $\begin{array}{r}13 \\
3\end{array}$ & $\begin{array}{r}12 \\
3\end{array}$ & $\begin{array}{l}8 \\
3\end{array}$ & $\begin{array}{l}2 \\
5 \\
0\end{array}$ & 5 & $\begin{array}{l}0.468 \\
0.044\end{array}$ & $\begin{array}{l}0.15 \\
0.425\end{array}$ & $\begin{array}{l}20 \cdot 1 \\
22 \cdot 2\end{array}$ & $\begin{array}{l}19 \\
18\end{array}$ & $\begin{array}{r}9-47 \\
10-48 \\
0\end{array}$ \\
\hline S011 & MA & $\mathbf{M}$ & 17 & 16 & 11 & 8 & ${ }^{-} 6$ & $\begin{array}{l}0.044 \\
0.493\end{array}$ & $\begin{array}{l}0.083 \\
0.650\end{array}$ & $\begin{array}{l}37.7 \\
22 \cdot 3\end{array}$ & $\begin{array}{l}25 \\
19\end{array}$ & $\begin{array}{l}20-68 \\
10-42\end{array}$ \\
\hline & MA & $\mathbf{F}$ & 4 & 4 & 2 & 2 & 1 & 0.325 & 0.325 & 19.5 & 20 & $13-25$ \\
\hline S023 & $\mathbf{M A}$ & $\underset{\mathbf{F}}{\mathbf{M}}$ & $\begin{array}{r}16 \\
3\end{array}$ & 14 & 8 & 4 & 4 & 0.450 & 0.267 & 17.4 & 18 & $8-28$ \\
\hline S056 & MA & $\mathbf{M}$ & $\begin{array}{l}3 \\
4\end{array}$ & $\begin{array}{l}2 \\
4\end{array}$ & $\begin{array}{l}1 \\
1\end{array}$ & $\begin{array}{l}1 \\
1\end{array}$ & $\begin{array}{l}1 \\
1\end{array}$ & $\overline{-}$ & $\begin{array}{l}0.75 \\
0.8\end{array}$ & $\begin{array}{l}18.5 \\
13\end{array}$ & $\begin{array}{l}18.5 \\
13.5\end{array}$ & $\begin{array}{r}17-20 \\
7-18\end{array}$ \\
\hline S079 & MA & $\mathbf{M}$ & $\begin{array}{l}0 \\
2 \\
0\end{array}$ & -2 & -2 & - & -2 & $\overline{0} .8$ & $\overline{0.8}$ & $\overline{17.5}$ & $\overline{17.5}$ & $\overline{16-19}$ \\
\hline Total & MA & $\mathbf{F}$ & $\underset{28}{179(86 \cdot 5 \%)}$ & $\begin{array}{r}146 \\
27\end{array}$ & $\begin{array}{l}99 \\
23\end{array}$ & $\begin{array}{l}61(61 \cdot 6 \%) \\
11(47 \cdot 8 \%)\end{array}$ & $\begin{array}{r}49(49 \cdot 5 \%) \\
8(34.9 \%)\end{array}$ & $\begin{array}{l}\overline{0} \cdot 442 \\
0.310\end{array}$ & $\begin{array}{l}\overline{0.4} \\
0.15\end{array}$ & $\begin{array}{l}- \\
22 \cdot 0 \\
24 \cdot 4\end{array}$ & $\overline{20}$ & $\begin{array}{r}- \\
7-58 \\
9-68\end{array}$ \\
\hline S068 & $\mathrm{MA}^{*}$ & $\mathbf{M}$ & $\begin{array}{r}20 \\
2 \\
0\end{array}$ & 2 & 2 & 1 & 0 & $0 \cdot 104$ & 0.104 & 23 & 23 & $9-37$ \\
\hline S081 & $M X$ & $\mathbf{M}$ & 1 & 1 & -0 & $z$ & $\bar{z}$ & $\overline{-}$ & $\begin{array}{l}- \\
-\end{array}$ & $\bar{z}$ & $-\overline{47}$ & $\bar{z}$ \\
\hline S026 & YA & $\mathrm{M}$ & $10(58 \cdot 9 \%)$ & $\begin{array}{l}8 \\
6\end{array}$ & $\begin{array}{l}0 \\
6 \\
5\end{array}$ & - & $\overline{0}$ & $\overline{0.048}$ & 0.017 & 19.1 & $\begin{array}{l}21.5 \\
19.5\end{array}$ & 16-22 \\
\hline S006 & $\mathbf{Y X}$ & $M$ & 17 & 16 & $\begin{array}{r}5 \\
13\end{array}$ & $\frac{1}{5}$ & $\begin{array}{l}0 \\
1\end{array}$ & $\begin{array}{l}0.081 \\
0.145\end{array}$ & $\begin{array}{l}0.033 \\
0.05\end{array}$ & $\begin{array}{l}21 \cdot 7 \\
20 \cdot 1\end{array}$ & $\begin{array}{l}18 \\
19\end{array}$ & $\begin{array}{r}10-40 \\
8-36\end{array}$ \\
\hline S051 & $Y X$ & $\mathrm{~F}$ & 4 & 4 & 3 & 1 & 0 & 0.127 & 0.08 & 31.5 & 31.5 & $28-35$ \\
\hline S051 & $\mathbf{Y X}$ & $\stackrel{M}{\mathrm{~F}}$ & $\begin{array}{l}2 \\
1\end{array}$ & $\begin{array}{l}2 \\
1\end{array}$ & $\begin{array}{l}2 \\
1\end{array}$ & $\begin{array}{l}1 \\
0\end{array}$ & 1 & 0.317 & $\begin{array}{l}0.317 \\
0.017\end{array}$ & 10 & 10 & ${ }_{-}^{3-17}$ \\
\hline Total & $\mathbf{Y X}$ & $\mathbf{M}$ & $19(79 \cdot 2 \%)$ & $\begin{array}{r}18 \\
5\end{array}$ & $\begin{array}{r}1 \\
4\end{array}$ & $\begin{array}{l}6(40.0 \%) \\
1(25.0 \%)\end{array}$ & $\begin{array}{l}2(13 \cdot 3 \%) \\
0(0 \%)\end{array}$ & $\begin{array}{l}0 \cdot 167 \\
0 \cdot 100\end{array}$ & $\begin{array}{l}0.05 \\
0.065\end{array}$ & $\begin{array}{l}- \\
18.9 \\
31.5\end{array}$ & $\begin{array}{l}-17.5 \\
31.5\end{array}$ & $\begin{array}{r}3-36 \\
28-35\end{array}$ \\
\hline
\end{tabular}


one type of mtDNA) for the 11778 mutation was found in two families. In family S055 (WB) a healthy female and both her healthy daughters are heteroplasmic, whereas the two affected sons of one of these daughters are homoplasmic; this family has been described elsewhere. ${ }^{22}$ In family S067 (WX) a healthy female, her affected brother, and affected son are heteroplasmic. Heteroplasmy for the 3460 mutation was found in both families in which the mutation occurs. In family S069 (HX) as well as in family S083 (HX) a healthy female is heteroplasmic but her affected son is homoplasmic. The clinical characteristics of these two patients are described elsewhere. ${ }^{23}$ The pedigrees investigated are listed in table 3.

SEX

Sex was scored in all 334 patients and in 66 more patients who are linked to one of the pedigrees and about whom little else is known than that they were presumed to suffer from LHON. The complete cohort therefore consists of 342 male and 58 female patients. The total numbers in each pedigree are listed in table 3.

AGE OF ONSET

The age of onset of the first visual complaints was scored in 326 of the 334 patients. Mean and median age of onset and range in each pedigree are listed in table 3.

FINAL VISUAL OUTCOME

Visual acuity of the best eye in the chronic stage of the disease was measured in 238 of the 334 patients. Because essential changes in visual acuity may occur especially in the first year after onset, the interval between age of onset and measurement of visual acuity had to be at least two years. However, visual acuity in the chronic stage may still change after this period. Visual acuities of patients with concomitant eye diseases, like amblyopia or glaucoma, were ruled out. The number of patients with a visual acuity of more than 0.1 and, among these, the ones with a visual acuity of more than or equal to 0.5 are listed in table 3 . Mean and median final visual outcome are also listed.

\section{Discussion}

Various mutation patterns were present in the LHON families investigated but not all possible combinations were found. Firstly, the 11778,3460 , and 14484 mutations did not occur simultaneously, nor did the 13708 and 4917 mutations. Secondly, the 4216 mutation occurred only in association with the 13708 or 4917 mutations. These findings are consistent with the results reported by Johns and Berman, ${ }^{11}$ Huoponen et al, ${ }^{13}$ Howell et al, ${ }^{14}$ Johns et al, ${ }^{24}$ Mackey and Howell, ${ }^{25}$ and Johns et al. ${ }^{26}$ Initially, the 15257 mutation was thought not to occur simultaneously with the 11778,3460 , or 14484 mutations, ${ }^{202127}$ but the only pedigree in this study with the 15257 mutation also exhibits the 14484, 13708, and 4216 mutations. Recently, Johns et $a l^{26}$ described 17 pedigrees with the 14484 mutation, four of which also carried the 15257 mutation.

In the 20 pedigrees investigated, the 11778 mutation was found 11 times $(51 \cdot 7 \%)$, which is in accordance with the results of others. ${ }^{791827}$ The 14484 mutation was present in nine of the 29 pedigrees $(31.0 \%)$, whereas Johns et $a l^{2}$ found this mutation in only $10 \%$ of the pedigrees they investigated. The 3460 mutation was found only twice $(6.9 \%)$ and the 15257 mutation only once (3.4\%), whereas Brown et $a l^{27}$ found these mutations in $15 \%$ and $9 \%$ of their pedigrees respectively.

The 4216 mutation may have little pathogenetic importance because it alters an evolutionarily unconserved amino acid and the prevalence in the LHON unrelated population is about $8 \%$ to $13 \% .^{1127}$ We therefore did not differentiate for the 4216 mutation.

The mutation patterns HX (only 3460), MA* (15257 with 14484,13708 , and 4216), and $M X$ (only 14484 ) were too scantily represented to make meaningful clinical comparisons and the three pedigrees concerned were, therefore, excluded from the statistical analyses. The clinical characteristics of the remaining groups, being WA (11778 with 13708), WB (11778 with 4917 and 4216 ), WX (only 11778 ), MA (14484 with 13708 and 4216), YA (only 13708 and 4216, and YX (none), show some distinct differences.

The mean age of onset in the male patients shows highly significant differences between the various groups (Kruskal-Wallis test: $\mathbf{H}(5$, $\mathrm{n}=273)=25.544, \mathrm{p}<0.0001)$. These include $\mathrm{a}$ significantly later age of onset in the WX group compared to the MA group $(p \leqslant 0.001)$, the YX group $(p \approx 0.01)$, and the YA group $(p \approx 0.05)$. The means of age of onset in the WA, WB, and WX groups do not differ significantly from each other. The mean final visual acuity of the best eye in the male patients also shows highly significant differences between the various groups (Kruskal-Wallis test: $\mathrm{H}(5$, $\mathrm{n}=193)=45.931, \quad \mathrm{p}<0.0001)$. These are caused by a significantly better final visual acuity in the MA group compared to the WA and WX groups (both $\mathrm{p} \leqslant 0.001$ ), to the YA group ( $p \approx 0.01)$, and to the WB and YX groups $(p \approx 0.05)$. It must be noted, however, that the final visual acuity in the MA group inclines to be binominally distributed. Of the 99 male patients, final visual acuity is equal to or more than 0.5 in $49(49.5 \%)$ and less than 0.1 in 39 patients $(38.3 \%)$, whereas only 12 patients $(12 \cdot 1 \%)$ have a final visual acuity between $0 \cdot 1$ and $0 \cdot 5$. Those medical records that were informative about this matter showed that a better visual outcome is very often caused by recovery after (severe) initial loss and only rarely results from a mildly elapsing acute stage. By contrast, in the WX group a final visual acuity equal to or more than 0.5 was present in only four of the 53 males $(7.6 \%)$; in two of them this was because of visual recovery. The means of final visual 
Table 4 Mean age of onset in each group for both sexes in relation to final visual acuity

\begin{tabular}{|c|c|c|c|c|c|c|c|c|c|c|c|c|}
\hline \multirow[b]{3}{*}{$F V A$} & \multicolumn{12}{|c|}{ Mean age of onset } \\
\hline & \multicolumn{2}{|l|}{$W A$} & \multicolumn{2}{|l|}{$W B$} & \multicolumn{2}{|l|}{$W X$} & \multicolumn{2}{|l|}{$M A$} & \multicolumn{2}{|l|}{$Y A$} & \multicolumn{2}{|l|}{$Y X$} \\
\hline & $M$ & $F$ & $M$ & $F$ & $M$ & $F$ & $M$ & $F$ & $M$ & $F$ & $M$ & $F$ \\
\hline $\begin{array}{l}\leqslant 0.1 \\
0.1-0.5 \\
\geqslant 0.5 \\
\text { Sionificance }\end{array}$ & $\begin{array}{c}(10) \\
26 \cdot 6 \\
(1) \\
52 \\
(1) \\
11\end{array}$ & $\begin{array}{r}(2) \\
19 \cdot 5 \\
(0) \\
-\quad(0) \\
-\end{array}$ & $\begin{array}{r}(7) \\
27 \cdot 3 \\
(0) \\
-\quad \\
(1) \\
17\end{array}$ & $\begin{array}{l}(0) \\
- \\
-(0) \\
-(0) \\
-\end{array}$ & $\begin{array}{c}(43) \\
28 \cdot 8 \\
(6) \\
31 \cdot 8 \\
(3) \\
14 \cdot 7\end{array}$ & $\begin{array}{c}(2) \\
35 \cdot 5 \\
(1) \\
35 \\
(1) \\
8\end{array}$ & $\begin{array}{l}(38) \\
23 \cdot 6 \\
(12) \\
17 \cdot 3 \\
(46) \\
20 \cdot 0\end{array}$ & $\begin{array}{r}(10) \\
30 \cdot 5 \\
(3) \\
25 \cdot 8 \\
(8) \\
18 \cdot 8\end{array}$ & $\begin{array}{c}(5) \\
20 \cdot 2 \\
(1) \\
16 \\
(0) \\
-\end{array}$ & $\begin{array}{c}(4) \\
20 \cdot 8 \\
(1) \\
16 \\
(0) \\
-\end{array}$ & $\begin{array}{r}(9) \\
20 \cdot 6 \\
(2) \\
12 \cdot 5 \\
(2) \\
16 \cdot 0\end{array}$ & $\begin{array}{c}(1) \\
35 \\
(0) \\
-\quad(0) \\
-\end{array}$ \\
\hline & NS & - & NS & - & NS & NS & $\mathrm{p} \approx 0.039$ & NS & NS & NS & NS & - \\
\hline
\end{tabular}

Numbers between ()$=$ number of affected persons in each group with known age of onset and final visual acuity.

NS $=$ not significant.

acuity in the WA, WB, and WX groups did not differ significantly from each other.

In all five groups mean age of onset appears to be lower in affected males with a final visual acuity equal to or more than 0.5 than in those with a final visual acuity equal to or less than $0 \cdot 1$, but only in the MA group is the difference slightly significant (table 4). This weak inversely proportional correlation is possibly explained by assuming some kind of mutation independent regeneration ability of the optic nerve, which is gradually lost with increasing age. This results in a lower final acuity as the disease starts later. Although the female populations appeared to be too small for statistically significant conclusions, they are comparable to the corresponding male populations with respect to the clinical results, especially in the larger groups. There is a slightly significant difference in sex ratios between the groups $\left(\chi^{2}\right.$ test $=11.98, p=0.036)$. This is entirely owing to the relatively large number of female patients in the YA group (7 of 17).

The clinical findings in the WA, WB, and WX groups are comparable with those of Newman et al..$^{28}$ They investigated 72 LHON patients in 43 families, all carrying the 11778 mutation. They found the age of onset to range from 8 to 60 years with a mean of 27.6 years and a final visual outcome of $20 / 200(0 \cdot 1)$ or worse in $98.2 \%$.

The clinical findings in the MA group are comparable with those of Mackey and How$\mathrm{ell}^{25}$ and of Johns et al. ${ }^{26}$ Mackey and Howell investigated 17 patients in two families carrying the 14484, 13708, and 4216 mutations but lacking the 11778,3460 , and 15257 mutations. Eight of the 17 patients they investigated $(47.0 \%)$ had a final visual acuity equal to or more than 0.5 . The age of onset ranged from 6 to 48 years. They found the mean age of onset to be 17 years in those who recovered visual acuity to more than $6 / 36(0 \cdot 17)$ and 34 years in those who did not. This difference appeared to be significant. Johns et $a l^{26}$ described 19 patients carrying the 14484 mutation, seven of whom experienced visual recovery to $20 / 60$ $(0.3)$ or more $(37 \%)$. Those patients had a mean age of onset of 19.6 years, whereas the other 12 patients, without visual recovery, had a mean age of onset of 30.6 years.

Heteroplasmy for both the 11778 and the 3460 mutation has been observed in LHON families. ${ }^{14182229-31}$ It has been suggested that the severity of visual impairment is reflected by the degree of heteroplasmy, that is, the amount of mutant mtDNA. ${ }^{31}$ In family $\mathrm{S} 067$ (WX) the two affected males, both heteroplasmic for the 11778 mutation, had a visual outcome of 0.1 and 0.2 respectively. Although their visual acuities do not differ much from the group mean, being $0 \cdot 113$, they both experienced a slight visual recovery after severe initial loss. This is not a usual finding in patients carrying the 11778 mutation and therefore upholds the aforementioned assumption. However, in contrast to other mitochondrial diseases, heteroplasmy is quite exceptional in LHON. It is only found in isolated cases and small pedigrees with patients in not more than two generations. Of the 29 LHON pedigrees we investigated, heteroplasmy for the mutation at np 11778 was found in only two small pedigrees, S055 (WB) and S067 (WX). We also found heteroplasmy in the mothers of the two singleton patients carrying the 3460 mutation (S069 and S083). Both patients were homoplasmic. ${ }^{25}$ Newman et $a l^{8}$ investigated $49 \mathrm{LHON}$ pedigrees positive for the mutation at np 11778 and found heteroplasmy in seven pedigrees, six of them represented by singleton cases. Moreover, various authors have reported rapid segregation of the heteroplasmic genotype in LHON, leading to mutant homoplasmy in the course of a few generations, as occurred in family S055 (WB). In this family the amount of mtDNA in leucocytes carrying the 11778 mutation was $60 \%$ in the unaffected grandmother, $55 \%$ in the unaffected mother, and more than $95 \%$ in her two sons both suffering from LHON. ${ }^{22}$ This has raised the idea that a heteroplasmic visually affected patient represents an early clinical manifestation of a de novo mutation. ${ }^{30}$ It is hypothesised that at some stage of oogenesis the several thousands of mtDNA molecules, present in each cell, are reduced to a small number. If a de novo mutant mtDNA molecule passes this bottleneck, its share in the total amount of mtDNA will increase considerably when the remaining number of molecules returns to its normal high level by means of replication. In that way, the mutation may become homoplasmic during the following two or three transmissions. ${ }^{32}$ This mechanism has been shown in bovine oocytes ${ }^{3233}$ and could be a crucial stage in the development of mitochondrial diseases, but it probably plays a limited part in the phenotypical heterogeneity of LHON, since it is rarely found in patients. As a consequence, leucocytes can be used for mutation analysis since the various tissues of a 
homoplasmic person will not differ in the amount of mutant mtDNA. On the other hand, heteroplasmy in other mitochondrial diseases, such as myoclonic epilepsy with ragged red fibres (MERRF) ${ }^{34}$ and neurogenic muscle weakness with ataxia and retinitis pigmentosa (NARP), ${ }^{35}$ is maintained in successive generations and apparently not acted upon by this bottleneck mechanism. The lethality of homoplasmy in these diseases has been postulated as the motive for maintaining heteroplasmy but a silent polymorphism at np 14560 , with no deleterious potential at all, has also been reported to occur persistently heteroplasmic. $^{36}$

The fact that the WA, WB, and WX groups do not differ significantly from each other with respect to the age of onset and final visual acuity sustains the assumption that the 13708 , 4917, and 4216 mutations are of dubious phenotypic importance. They may even represent neutral polymorphisms with a higher incidence in LHON families than in normal controls. ${ }^{27}$ No LHON patients were reported in family S055 (WB), featuring the 4917 and 4216 mutation in combination with the 11778 mutation, before the appearance of homoplasmy for the 11778 mutation. Therefore, we suppose that another mutation must be present in families like S026, which lack the 11778, 3460 , and 14484 mutations. This putative mutation may also account for the high penetrance of the disease in females, which characterises this pedigree.

It has been suggested that the occurrence of certain additional mutations may act synergistically and thus be responsible for a more severe clinical outcome. ${ }^{27}$ The occurrence of the 15257 mutation in 14484 positive pedigrees, like family S068 (MA*), may thus account for the worse mean visual outcome, compared to the 14484 positive pedigrees that do not feature the 15257 mutation. Johns et $a^{26}$ described five patients carrying both the 14484 and 15257 mutations, four of whom experienced no visual recovery.

As yet, no mtDNA mutations have been found in the YX group pedigrees. One of these, family S006 (YX) differs from all the other pedigrees in that neurological abnormalities consistently correlated with LHON are only found in this family. Nine of the 21 LHON patients in this family and three of their visually unaffected matrilineal sibs suffer from divergent mild to severe central nervous system disorders, especially hyperreflexia, spastic para- or tetraparesis, bulbar dysarthria, and ataxia. ${ }^{1-4} \mathrm{~A}$ more deleterious mutation may, therefore, be present in this pedigree compared to the other one in this group.

The existence of intragenic suppressor mutations that ameliorate the mitochondrial deficiency has been proposed. ${ }^{8}$ Such a mutation could be present in family S018 (WX). In this family, the largest in the WX group, the affected males have a mean final visual outcome of 0.193 , which is more than one and a half times as much as the group mean $(0 \cdot 113)$ and more than four to six times as much as the means of the other three large families (S014, S022, and
S025). Moreover, all the males in the WX group with a final visual acuity equal to or more than 0.5 belong to this pedigree.

We conclude that LHON patients who exhibit the mtDNA mutations at np 14484, 13708 , and 4216 but lack the 11778,3460 , and 15257 mutations have a significantly lower mean age of onset and better mean final visual outcome than patients exhibiting the 11778 mutation and that the mutations at np 13708, 4917, and 4216 do not make a significant contribution to the clinical severity. Further investigation of mtDNA mutation patterns and clinical findings will contribute to the clarification of pathogenesis in LHON.

The authors would like to thank Jan M Ruijter for the statistical analyses of the results.

1 Van Senus AHC. Leber's disease in the Netherlands. Thesis, University of Leiden, 1963

2 Went LN. A sex-linked heredo-degenerative neurological disorder associated with Leber's optic atrophy. Genera aspects. Acta Genet (Basel) 1964;14:220-39.

3 Went LN, Bruyn GW. The genetics of Leber's atrophy and its neurological sequelae. 手 Genet Hum 1966;15:332-7.

4 de Weerdt CJ. Neurological studies on Leber's optic atrophy. Thesis, University of Leiden, 1969.

5 de Weerdt CJ, Went LN. Neurological studies in families with Leber's optic atrophy. Acta Neurol Scand 1971;47:541-54.

6 Palan A, Stehouwer A, Went LN. Studies on Leber's optic neuropathy III. Doc Ophthalmol 1989;71:77-92.

7 Howell N, McCullough D. An example of Leber hereditary optic neuropathy not involving a mutation in the mitooptic neuropathy not involving a mutation in the mito-
chondrial ND4 gene. Am $\mathcal{F}$ Hum Genet 1990;47:629-34.

8 Howell N, Kubacka I, Xu M, McCullough DA. Leber hereditary optic neuropathy: involvement of the mitohereditary optic neuropathy: involvement of the mito-
chondrial ND1 gene and evidence for an intragenic suppressor mutation. Am $\mathcal{f}$ Hum Genet 1991; 48:935-42.

9 Wallace DC, Singh G, Lott MT, et al. Mitochondrial DNA mutations associated with Leber's hereditary optic neuropathy. Science 1988;242:1427-30.

10 Vilkki J, Savontaus ML, Nikoskelainen EK. Genetic heterogeneity in Leber hereditary optic neuroretinopathy revealed by mitochondrial DNA polymorphism. $A m$ Hum Genet 1989;45:206-11.

11 Johns DR, Berman J. Alternative, simultaneous complex 1 mitochondrial DNA mutations in Leber's hereditary optic neuropathy Biochem Biophys Res Commun 1991;174:1324-30.

12 Wallace DC. Diseases of mitochondrial DNA. Annu Rev Biochem 1992;61:1175-212.

13 Huoponen $\mathrm{K}$, Vilkii J, Aula $\mathrm{P}$, et al. A new mtDNA mutation associated with Leber hereditary optic neuromutation associated with Leber hereditary optic

14 Howell N, Bindoff LA, McCullough DA, et al. Leber hereditary optic neuropathy: identification of the same mitochondrial ND1 mutation in six pedigrees. $\mathrm{Am} \mathcal{F} \mathrm{Hum}$ Genet 1991; 49:939-50.

15 Seedorf $\mathrm{T}$. The inheritance of Leber's disease: a genealogical follow-up study. Acta Ophthalmol 1985;63:135-45.

6 Vilkki J, Ott J, Savontaus MJ, et al. Optic atrophy in Leber hereditary optic neuroretinopathy is probably determined by an X-chromosomal gene closely linked to DXS7. Am Hum Genet 1991;48:486-91.

$17 \mathrm{Bu} \mathrm{X}$, Rotter JI. X chromosome-linked and mitochondrial gene control of Leber hereditary optic neuropathy: evidence from segregation analysis for dependence on $C$ chromosome inactivation. Proc Natl Acad Sci USA 1991;88:8198-202.

18 Holt IJ, Miller DH, Harding AE. Genetic heterogeneity and mitochondrial DNA heteroplasmy in Leber's herediand mitochondrial DNA heteroplasmy in Leber's heredi-

19 Hiida Y, Mashima Y, Oguchi Y, et al. Mitochondrial DNA analysis of Leber's hereditary optic neuropathy. $\mathfrak{f p}_{p} \mathcal{F}$ Ophthalmol 1991;35:102-6.

20 Johns DR, Neufeld MJ. Cytochrome b mutations in Leber hereditary optic neuropathy. Biochem Biophys Res Commun 1991;181:1358-64.

21 Johns DR, Neufeld MJ, Park RD. An ND-6 mitochondrial DNA mutation associated with Leber hereditary optic neuropathy. Biochem Biophys Res Commun 1992;187:1551-7.

22 Bolhuis PA, Bleeker-Wagemakers EM, Ponne NJ, et al. Rapid shift in genotype of human mitochondrial DNA in a family with Leber's hereditary optic neuropathy. Biochem Biophys Res Commun 1990;170:994-7.

23 Oostra RJ, Bolhuis PA, Bleeker-Wagemakers EM. Mitochondrial DNA analysis as a diagnostic tool in singleton cases of Leber's hereditary optic neuropathy. Paediatr Genet 1993;14:109-15.

24 Johns DR, Smith HK, Miller NR. Leber's hereditary optic neuropathy. Clinical manifestations of the 3460 mutation.

25 Mackey D, Howell N. A variant of Leber hereditary optic neuropathy characterized by recovery of vision and by an 
unusual mitochondrial genetic etiology. Am $\mathcal{f}$ Hum Genet 1992;51:1218-28.

26 Johns DR, Heher KL, Miller NR, et al. Leber's hereditary optic neuropathy. Clinical manifestations of the 14484 mutation. Arch Ophthalmol 1993;111:495-8.

27 Brown MD, Voljavec AS, Lott MT, et al. Leber's hereditary optic neuropathy: a model for mitochondrial neurotary optic neuropathy: a model for mitoch

28 Newman NJ, Lott MT, Wallace DC. The clinical characteristics of pedigrees of Leber's hereditary optic neuroteristics of pedigrees of Leber's hereditary optic neuropathy with the

29 Vilkki J, Savontaus ML, Nikoskelainen EK. Segregation of mitochondrial genomes in a heteroplasmic lineage with Leber hereditary optic neuroretinopathy. $\mathrm{Am} \mathscr{\mathcal { F }} \mathrm{Hum}$ Genet 1990;47:95-100.

30 Lott MT, Voljavec AS, Wallace DC. Variable genotype of Leber's hereditary optic neuropathy patients. $\mathrm{Am} \mathcal{J} \mathrm{Oph}$ thalmol 1990;109:625-31.
31 Isashiki Y, Nakagawa M. Clinical correlation of mitochondrial DNA heteroplasmy and Leber's hereditary optic neuropathy. Jpn f Ophthalmol 1991;35:259-67.

32 Hauswirth WW, Laipis PJ. Rapid segregation of heteroplasmic bovine mitochondria. Proc Natl Acad Sci USA 1982;79:4686-90.

33 Ashley MV, Laipis PJ, Hauswirth WW. Rapid segregation of heteroplasmic bovine mitochondria. Nucleic Acids Res 1989;17:7325-31.

34 Shoffiner JM, Lott MT, Lezza AMS, et al. Myoclonic epilepsy and ragged-red fiber disease (MERRF) is associated with a mitochondrial DNA tRNA ${ }^{\text {lys }}$ mutation. Cel ated with a mitoc.

35 Holt IJ, Harding AE, Petty RKH, Morgan-Hughes JA. A new mitochondrial disease associated with mitochondrial DNA heteroplasmy. Am $\mathcal{f}$ Hum Genet 1990;46:428-33. 36 Howell N, Halvorsson S, Kubacka I, et al. Mitochondrial gene segregation in mammals: is the bottleneck narrow? Hum Genet 1992;90:117-20. 